\title{
EFEKTIVITAS PELATIHAN KOIN JIWA DALAM MENURUNKAN STIGMA TERHADAP ORANG DENGAN GANGGUAN JIWA PADA MAHASISWA
}

\author{
Elok Farida Husnawati dan Ratna Supradewi \\ Fakultas Psikologi \\ Universitas Islam Sultan Agung Semarang \\ Email: elokfaridaa@gmail.com; supradewi@unissula.ac.id
}

\begin{abstract}
Abstrak
Orang yang mengalami gangguan jiwa sangat rentan mendapatkan perlakuan buruk dari masyarakat (Corrigan, Roe, and Tsang 2011). Penelitian terdahulu menyatakan bahwa selain harus berjuang melawan gangguan yang dialami, Orang dengan Gangguan Jiwa (ODGJ) juga harus menghadapi stigma dari masyarakat. Stigma terhadap ODGJ merupakan suatu tanda atau label negatif yang diikuti oleh usaha untuk menjelekkan ODGJ (Byrne 2000). Stigma tidak hanya dilakukan oleh orang awam saja, bahkan orang dengan pendidikan yang cukup tentang gangguan jiwa juga masih memiliki stereotipe negatif terhadap ODGJ (Corrigan and Watson 2002). Hal tersebut didukung oleh hasil preliminary study, yang menyatakan bahwa Mahasiswa Fakultas Psikologi Unissula yang notabene-nya mempelajari ilmu kejiwaan pun masih memiliki stigma terhadap ODGJ.Stigma terhadap ODGJ menimbulkan berbagai dampak buruk, seperti penganiayaan, pemasungan, penghindaran, hingga peniadaan hak asasi manusia. Psikoedukasi dapat menjadi salah satu cara untuk menurunkan stigma terhadap ODGJ. Psikoedukasi dapat membantu masyarakat mengetahui informasi yang cukup tentang gangguan jiwa. Bentuk psikoedukasi yang diberikan pada penelitian ini adalah Pelatihan Koin Jiwa (psiKOedukasi pedull gangguaN JIWA), dengan materi mengenai pengetahuan dan cara menangani ODGJ. Penelitian ini menggunakan metode eksperimental dengan desain pre-test - post-test control group design. Alat ukur yang digunakan dalam penelitian ini adalah AQ-27 yang dialihbahasakan ke dalam Bahasa Indonesia $(r=0,87)$. Hasil penelitian menunjukkan bahwa terdapat perbedaan yang signifikan antara skor kelompok eksperimen dengan kelompok kontrol setelah pemberian Pelatihan Koin Jiwa $(t=-5,130, p=0$ (one-tailed)). Hasil penelitian tersebut membuktikan bahwa Pelatihan Koin Jiwa dapat menurunkan stigma terhadap ODGJ pada Mahasiswa Fakultas Psikologi Unissula.
\end{abstract}

Kata kunci: stigma terhadap orang dengan gangguan jiwa, psikoedukasi, pelatihan

\section{EFFECTIVENESS OF KOIN JIWA TRAINING TO REDUCE STIGMA TOWARD PEOPLE WITH MENTAL ILLNESS AMONG STUDENTS}

\begin{abstract}
People with mental illness are particularly vulnerable to bad treat (Corrigan, Roe, \& Tsang, 2011). Previous research states that in addition to struggling against the illness, People with Mental ilness must also face the public stigma. The stigma of mental illness is a sign or a negative label followed by an attempt to discredit the people with mental illness (Byrne, 2000). Stigma is not only done by general people, even well-educated people also still have a negative stereotype about mental illness (Corrigan \& Watson, 2002). This is supported by the results of preliminary studies, which states students Faculty of Psychology Unissula who is studying psychology was still a stigma toward people with mental illness. Stigma toward people with mental illness has many adverse effects, such as torture, deprivation, avoidance, to the exclusion of human rights. Psychoeducation can be one of the way to reduce stigma toward people with mental illness. The psychoeducation given in this study is Pelatihan Koin Jiwa (psiKOedukasi pedull gangguaN JIWA) with information about knowledge and how to treat people with mental illness. This research uses experimental method with pre-test - post-test control group design. The measuring instrument used in this study is $A Q-27$ which is converted in Indonesian language ( $r=$ 0.87). The results showed a significant difference score between the experimental group and the control group
\end{abstract}


after being given Pelatihan Koin Jiwa ( $t=-5,130, p=0$ (one-tailed)). The results were proven Pelatihan Koin Jiwa can reduce stigma toward people with mental illness in Student Faculty of Psychology Unissula.

Keywords: stigma toward people with mental illness, psychoeducation, training

\section{PENDAHULUAN}

Orang dengan gangguan jiwa atau yang dapat disebut dengan (ODGJ) sangat rentan mendapatkan perlakuan buruk dari masyarakat (Corrigan, Roe, and Tsang 2011). Bentuk-bentuk perlakuan buruk yang diterima oleh ODGJ, antara lain penganiayaan, penghindaran, hingga peniadaan hak asasi manusia.Berbagai berita baik di media cetak maupun di media sosial banyak menunjukkan terjadinya perlakuan buruk kepada ODGJ.Penelitian terdahulu juga mendukung adanya bukti di lapangan bahwa ODGJ selain harus berjuang melawan gangguan jiwa yang dialami, juga harus menghadapi stereotipe dan prasangka yang berasal dari kesalahpahaman terhadap penyakit kejiwaan (Corrigan and Watson 2002) hal tersebut dapat disebut dengan stigma terhadap ODGJ.

Stigma adalah suatu label buruk atau usaha untuk menjelekkan orang yang diberi stigma, sehingga dapat memisahkan hubungan sosial antara orang yang diberi stigma dengan orang lain (Byrne 2000). Sedangkan stigma terhadap ODGJ merupakan prasangka dan diskriminasi yang digeneralisasikan kepada ODGJ, sehingga memiliki dampak yang menyebabkan terhalangnya akses mereka dalam mendapatkan pekerjaan, peluang pendidikan, fasilitas kesehatan yang memuaskan (Ciftci, Jones, and Corrigan 2013), tempat tinggal yang aman, dan kesempatan melakukan afiliasi dengan berbagai kelompok (Corrigan and Watson 2002). Bentuk yang lebih ekstrim seperti penghindaran atau isolasi sosial untuk meminimalisir interaksi dengan ODGJ, dan juga keengganan masyarakat dalam membantu penyembuhan gangguan jiwa yang diderita(Corrigan and Watson 2002).

Stigma tidak hanya dilakukan oleh masyarakat umum atau awam. Menurut Corrigan \& Watson (2002) menyatakan bahwa orang dengan pendidikan yang cukup tentang orang dengan gangguan jiwa juga masih memiliki stereotipe negatif terhadap orang dengan gangguan jiwa. Hal tersebut mendorong peneliti untuk melakukan preliminary study kepada Mahasiswa Fakultas Psikologi Unissula. Mahasiswa Fakultas Psikologi Unissula yang notabene-nya mempelajari tentang ilmu kejiwaan dan kelak akan menangani masalah-masalah kejiawaan.

Berdasarkan preliminary study yang telah dilakukan, menunjukkan bahwa mahasiswa psikologi masih memiliki stigma terhadap orang dengan gangguan jiwa.Bentuk stigma yang dimunculkan salah satunya yaitu melakukan penghindaran, merasa takut dengan keberadaan orang dengan gangguan jiwa, merasa kasihan atas penyakit yang diderita, dan memilih untuk tidak melakukan interaksi pada orang dengan gangguan jiwa.Gangguan jiwa yang paling terstigma oleh Mahasiswa Fakultas Psikologi Unissula adalah skizofrenia, bipolar, dan depresi berat.

Berdasarkan barbagai pemaparan diatas, maka perlu dilakukan penanganan yang lebih serius dalam menurunkan stigma terhadap ODGJ.Menurut Corrigan \& Penn (1999) (dalam Corrigan \& Watson, 2002) menjelaskan cara yang efektif untuk merubah stigma masyarakat terhadap ODGJ, yaitu melalui 3 pendekatan, 1) Membentuk kelompok yang bertugas memprotes informasi yang salah terhadap orang dengan gangguan jiwa, 2) Memberikan pengetahuan yang cukup tentang orang dengan gangguan jiwa dan cara menanganinya, dan 3) melakukan kontak langsung terhadap orang dengan gangguan mental. 
Pendekatan dengan memberikan pengetahuan secara intensif dapat disebut dengan pendekatan psikoedukasional. Pendekatan psikoedukasional dapat membantu masyarakat mengetahui informasi yang cukup tentang gangguan jiwa. Masyarakat yang memiliki pengetahuan dan cara menangani orang dengan gangguan jiwa yang baik juga dapat memperlakukan mereka dengan lebih baik (Corrigan and Watson 2002). Berdasarkan pemaparan diatas, peneliti menawarkan upaya untuk mengurangi stigma terhadap orang dengan gangguan jiwa, dengan memberikan pengetahuan secara intensif tentang gangguan jiwa dan cara penanganan.

Bentuk psikoedukasi yang diberikan berupa Pelatihan Koin Jiwa (PsiKOedukasi pedull gangguaN JIWA). Pelatihan merupakan salah satu cara untuk membantu menguasai keterampilan tertentu sehingga dapat memperbaiki kekurangan (Aruan 2013). Pelatihan Koin Jiwa berisi tentang pengetahuan mengenai berbagai jenis gangguan jiwa, fakta tentang pemeriksaan (atau proses diagnosis), penanganan gangguan jiwa, dan membandingkan mitos dengan fakta tentang gangguan jiwa yang berlaku di masyarakat.

\section{STIGMA TERHADAP ORANG DENGAN GANGGUAN JIWA}

Stigma berasal dari bahasa Yunani yang artinya suatu hal yang memalukan, noda, atau suatu tanda untuk mengidentifikasi suatu karakteristik tertentu (Overton and Medina 2008), sehingga orang lain akan tahu gambaran diri orang-orang yang terstigma, dan mereka harus dijauhi (Arboleda$\mathrm{Fl}^{\prime}$ orez and Sartorius 2008). Stigma merupakan suatu kondisi ketikdakadilan sosial dimana terdapat usaha untuk memberikan label buruk kepada seseorang atau kelompok tertentu, sehingga menimbulkan kerugian bagi orang atau kelompok yang diberi stigma (Corrigan, Roe, and Tsang 2011).

Terdapat berbagai macam stigma, salah satunya yaitu stigma terhadap Orang dengan Gangguan Jiwa (ODGJ). Stigma terhadap ODGJ adalah prasangka yang juga melibatkan diskriminasi, kemudian digeneralisasikan kepada ODGJ. Hal tersebut berdampak luas dan dapat membahayakan kehidupan orang dengan gangguan jiwa (Corrigan et al. 2012), seperti ketidakadilan dan konsekuensi yang merugikan (Ciftci, Jones, and Corrigan 2013), sulit mendapatkan rumah yang nyaman, dan hubungan intim dengan pasangan (Corrigan, Roe, and Tsang 2011), kesulitan untuk mencari pekerjaan sehingga menimbulkan ketidakmampuan untuk memenuhi kebutuhannya sendiri (Corrigan, Druss, and Perlick 2014), dan pengucilan sosial dari lingkungan kerja, sekolah, rumah, dan dari berbagai kegiatan sosial lain (Thornicroft et al. 2008).

Sebelum era modern seperti saat ini gangguan jiwa sering dianggap sebagai hukuman dari Tuhan atau adanya roh jahat didalam tubuh (Corrigan, Roe, and Tsang 2011). Kepercayaan ini masih bertahan hingga abad pertengahan dan tidak menutup kemungkinan hingga saat ini masih ada beberapa orang yang mempercayai hal tersebut.Menurut Johnstone (2001) berbagai perspektif medis telah berusaha menjelaskan secara ilmiah tentang gangguan jiwa. Gangguan jiwa secara ilmiah lebih mengacu pada kegagalan aspek kognitif, afektif, dan konatif yang dapat menghambat hubungan intrapersonal juga tugas-tugas sehari-hari seperti bekerja, memenuhi kebutuhan, dan lainlain (dalam Overton \& Medina, 2008). Beberapa peneliti lain memiliki pendapat, gangguan jiwa memiliki dampak yang cukup besar pada perasaan atau afek, persepsi, kognisi, motivasi, tingkah laku, dan fungsi interpersonal (Corrigan, Druss, and Perlick 2014).

Berbagai macam penjelasan medis yang telah dipaparkan diatas pun belum mampu merubah konsep buruk mengenai gangguan jiwa. Hal tersebut terjadi karena gangguan jiwa dianggap sebagai 158 P-ISSN 1907-8455 
suatu ketidakmampuan individu dalam menyesuaikan diri dengan lingkungan sosial (Overton and Medina 2008), sehingga menyebabkan banyaknya perlakuan buruk kepada ODGJ.Orang dengan gangguan jiwa dianggap membahayakan orang lain, tidak dapat diprediksi, sulit diajak berkomunikasi atau berinteraksi, tempat untuk disalahkan, berbeda dengan yang lain, tidak akan pernah sembuh, tidak akan pernah membaik, dan dianggap telah menarik diri dari lingkungan sosialnya (Crisp et al. 2000).

\section{PELATIHAN KOIN JIWA (PSIKOEDUKASI PEDULI GANGGUAN JIWA)}

Stigma terhadap orang dengan gangguan jiwa merupakan permasalahan serius yang harus segera ditindak-lanjuti. Salah satu cara untuk menindak-lanjuti hal tersebut yaitu dengan menurunkan pengaruh dari stigma yang telah melekat pada masyarakat. Perlunya dilakukan 3 pendekatan untuk menurunkan stigma, yaitu dengan pemberian pengetahuan, protes, dan melakukan kontak langsung (Corrigan et al. 2012; Corrigan, Roe, and Tsang 2011). Peneliti mengusulkan psikoedukasi sebagai salah satu pendekatan yang cukup efektif dalam menurunkan stigma terhdap orang dengan gangguan jiwa (Byrne 2000; Corrigan et al. 2012; Corrigan, Roe, and Tsang 2011). Pemberian pengetahuan bertujuan untuk memberikan jawaban mengenai gangguan jiwa, selain menjawab pertanyaan yang mendasar mengenai orang dengan gangguan jiwa, pemberian pengetahuan ini juga dapat memberikan keterampilan kepada masyarakat untuk dapat memperlakukan orang dengan gangguan jiwa secara tepat (Corrigan, Roe, and Tsang 2011). Psikoedukasi yang diberikan akan dibuat menjadi lebih spesifik, dengan tujuan mempermudah dalam peneliti membandingkan 2 kondisi. Psikoedukasi yang dipilih yaitu dengan memberikan pelatihan yang berisi tentang pengetahuan dan cara menangani orang dengan gangguan jiwa. Pelatihan ini dinamakan Pelatihan Koin Jiwa (psiKOedukasi pedull gangguaN JIWA).

Pelatihan merupakan proses pemberian informasi yang dilakukan dalam jangka waktu yang singkat, sistematis, dan terorganisir, digunakan untuk tujuan tertentu (Munandar 2008). Menurut Nawawi (2003), pelatihan didefinisikan sebagai suatu proses untuk membantu mendalami keterampilan khusus sehingga dapat memperbaiki kekurangan yang dimiliki,

Materi pelatihan dalam penelitian ini akan merujuk dari program edukasi yang dirancang oleh Corrigan et al. (2011) dalam buku "Challenging The Stigma of Mental Illness". Pelatihan ini berisi tentang pengetahuan mengenai berbagai jenis gangguan jiwa, fakta tentang pemeriksaan (atau proses diagnosis) dan penanganan gangguan jiwa, dan membandingkan mitos dengan fakta tentang gangguan jiwa yang berlaku di masyarakat.

\section{METODE PENELITIAN}

Penelitian ini menggunakan metode penelitian eksperimen psikologis. Desain eksperimen dalam penelitian ini menggunakan pre-test - post-test control group design.Teknik pengambilan sampel dalam penelitian ini menggunakan teknik purposive random sampling.

Kriteria khusus untuk menjadi sampel penelitian adalah Mahasiswa Fakultas Psikologi Unissula angkatan 2015 yang memiliki skor stigma terhadap orang dengan gangguan jiwa dengan kategori tinggi.Kriteria khusus tersebut didapatkan setelah melakukan seleksi subjek kepada seluruh Mahasiswa Fakultas Psikologi Unissula angkatan 2015. Sampel penelitian yang memenuhi kriteria khusus akan dikelompokkan kedalam kelompok eksperimen atau kelompok kontrol menggunakan random assignment (randomisasi). 


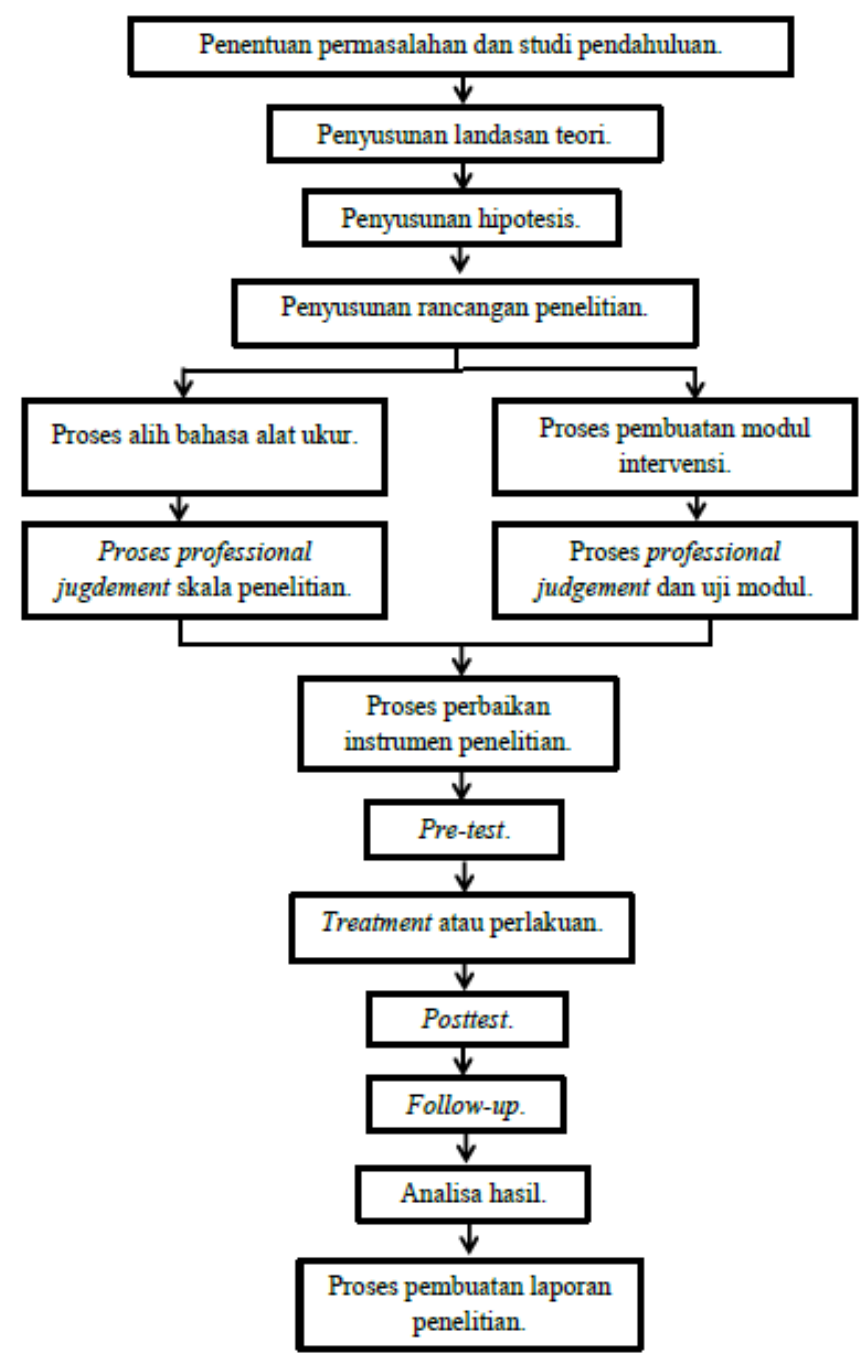

Gambar 1. Langkah-langkah Penelitian

Pengumpulan data dalam penelitian ini menggunakan skala stigma terhadap orang dengan gangguan jiwa yang dibuat oleh Patrick William Corrigan. Skala tersebut menggunakan Bahasa Inggris, sehingga perlu di alih bahasakan menjadi Bahasa Indonesia. Skala tersebut bernama AQ-27. Skala AQ-27 terdiri dari 27 aitem, dan terdapat 9 komponen stigma terhadap orang dengan gangguan jiwa. Hal tersebut menunjukkan bahwa dalam 1 komponen terdiri dari 3 aitem. Komponenkomponen tersebut adalah menyalahkan (blame), marah (anger), kasihan (pity), menolong (help), berbahaya (dangerousness), rasa takut (fear), menghindar (avoidance), pemisahan (segregation), paksaan (coercion). Estimasi koefisien reliabilitas alat ukur skala AQ-27 adalah 0,87 (Foster et al. 2014).

Skala AQ-27 diawali dengan cerita mengenai Rudi yang mengalami gangguan jiwa. Rudi berusia 30 tahun, bekerja sebagai konsultan hukum, dan hidup sendiri di suatu kos. Aitem dari skala ini terdari beberapa pernyataan dan pertanyaan dengan skor yang bergerak dari 1 hingga 9.Pilihan jawaban setiap aitem bergerak dari "sangat tidak setuju" hingga "sangat setuju".

Skala ini digunakan untuk melakukan pre-test, post-test, dan follow up dari penelitian ini. Hal tersebut dimaksudkan untuk mengukur kondisi awal atau baseline sebelum pelatihan, kemudian 
menggukur perubahan yang terjadi setelah partisipan mengikuti pelatihan, serta mengukur sejauh mana efek dari pelatihan dapat bertahan. Skala pre-test merupakan skala AQ-27 yang diambil 9 aitem dari keseluruhan (meliputi 9 komponen, dengan 1 aitem setiap komponennya), skala post-test terdiri dari 9 aitem yang berbeda dari pre-test (meliputi 9 komponen, dengan 1 aitem setiap komponennya), dan skala follow up terdiri dari 9 aitem (meliputi 9 komponen, dengan 1 aitem setiap komponennya). Hal tersebut bertujuan untuk menghindari adanya bias memory pada sampel penelitian.

\section{HASIL}

Analisa data yang cocok digunakan dalam penelitian ini adalah uji statistik Paired T-Test (Seniati, Yulianto, \& Setiadi 2015; Sugiyono 2014). Hasil uji statistik Paired T-Testuntuk melihat kondisi awal (baseline) menunjukkan $\mathrm{t}=-0,698$ dengan $\mathrm{p}=0,2475$ (one-tailed) $>0,05$ sehingga dapat disimpulkan tidak ada perbedaan pada skor awal kedua kelompok. Hal tersebut menunjukkan bahwa baseline kedua kelompok berada pada kondisi yang setara.Pengujian hipotesis dilakukan dengan menggunakan teknik analisa Paired T-Test pada skor post-test kelompok eksperimen dan kelompok kontrol. Hasil yang didapatkan yaitu $\mathrm{t}=-5,130$ dengan $\mathrm{p}=0$ (one-tailed) $<0,01$ menunjukkan adanya perbedaan yang signifikan antara skor kelompok eksperimen dengan kelompok kontrol setelah pemberian Pelatihan Koin Jiwa. Berdasarkan analisa data yang telah dilakukan menunjukkan bahwa hipotesis penelitian ini diterima.

Sumbangan efektif yang diberikan oleh Pelatihan Koin Jiwa sebanyak $24 \%$, sedangkan $76 \%$ merupakan sumbangan dari faktor lain. Hasil data follow-up dibagi menjadi 2, yaitu kelompok eksperimen dan kelompok kontrol. Kedua kelompok dianalisa mengguankaan Paired $T$ Test.Berdasarkanhasil hitungan kelompok eksperimen menunjukkan bahwa nilai $t=0,533$ dengan $p=$ 0,301 (one-tailed) $>0,05$. Hal tersebut menunjukkan bahwa tidak terdapat perbedaan pada skor post-test dengan follow-up pada kelompok eksperimen. Kelompok kontrol menunjukkan hasil yang berbeda, dengan nilai $t=3,085$ dengan $p=0,0035$ (one-tailed) $<0,01$. Pada kelompok kontrol terdapat perbedaan skor post-test dengan follow-up. Pemberian follow-up yang berlangsung kurang lebih 20 hari setelah pengambilan data post-test. Kesimpulan dari perhitungan tersebut yaitu pengaruh Pelatihan Koin Jiwa masih berdampak hingga kurang lebih 20 hari saat pengambilan data follow-up pada kelompok eksperimen.

Manipulation check pada penelitian ini diberikan untuk kelompok eksperimen berupa tes pengetahuan, guna melihat perbedaan antara kelompok yang diberi pelatihan dengan kelompok yang tidak diberi pelatihan. Berdasarkan kategorisasi data tes pengetahuan, maka dapat disimpulkan bahwa peserta pelatihan memperoleh skor tes pengetahuan yang berada pada kategori sedang hingga tinggi.

Evaluasi pelatihan dilakukan untuk melihat kepuasan peserta pelatihan terhadap program Pelatihan Koin Jiwa. Berdasarkan kategorisasi evaluasi pelatihan terdapat $52,9 \%$ peserta yang menyatakan puas dan $47,1 \%$ yang menyatakan sangat puas terhadap program pelatihan ini. Selain pernyataan kepuasan juga terdapat pemberian kritik dan saran untuk Pelatihan Koin Jiwa. Kritik yang diberikan antara lain pemberian materi yang kurang aktraktif, games yang kurang menarik, dan pemilihan waktu yang kurang tepat. Saran yang diberikan supaya pelatihan dapat selesai dengan lebih tepat waktu. 


\section{PEMBAHASAN}

Penelitian ini bertujuan untuk melihat penurunan stigma terhadap orang dengan gangguan jiwa pada Mahasiswa Fakultas Psikologi Unissula setelah pemberian Pelatihan Koin Jiwa dibanding sebelum Pelatihan Koin. Hasil analisis penelitian ini dilakukan dengan bantuan program komputer Statistical Package for the Social Sciences (SPSS) versi 20.0, yang menggunakan uji statistik Paired T-Test. Hasil uji statistik Paired T-Test untuk melihat kondisi awal (baseline) menunjukkan $\mathrm{t}=-0,698$ dengan $\mathrm{p}=0,2475$ (one-tailed) $>0,05$ sehingga dapat disimpulkan tidak ada perbedaan pada skor awal kedua kelompok. Hal tersebut menunjukkan bahwa baseline kedua kelompok berada pada kondisi yang setara. Pengujian hipotesis dilakukan dengan menggunakan teknik analisa Paired T-Test pada skor post-test kelompok eksperimen dan kelompok kontrol. Hasil yang didapatkan yaitu $\mathrm{t}=-5,130$ dengan $\mathrm{p}=0$ (one-tailed) $<0,01$ menunjukkan adanya perbedaan yang signifikan antara skor kelompok eksperimen dengan kelompok kontrol setelah pemberian Pelatihan Koin Jiwa. Berdasarkan analisa data yang telah dilakukan menunjukkan bahwa hipotesis penelitian ini diterima.

Sumbangan efektif yang diberikan oleh Pelatihan Koin Jiwa sebanyak $24 \%$, sedangkan $76 \%$ merupakan sumbangan dari faktor lain. Hasil data follow-up dibagi menjadi 2, yaitu kelompok eksperimen dan kelompok kontrol. Kedua kelompok dianalisa mengguankaan Paired T-Test. Berdasarkan hasil hitungan kelompok eksperimen menunjukkan bahwa nilai $t=0,533$ dengan $p=$ 0,301 (one-tailed) $>0,05$. Hal tersebut menunjukkan bahwa tidak terdapat perbedaan pada skor post-test dengan follow-up pada kelompok eksperimen. Kelompok kontrol menunjukkan hasil yang berbeda, dengan nilai $t=3,085$ dengan $p=0,0035$ (one-tailed) $<0,01$. Pada kelompok kontrol terdapat perbedaan skor post-test dengan follow-up. Pemberian follow-up yang berlangsung kurang lebih 20 hari setelah pengambilan data post-test. Kesimpulan dari perhitungan tersebut yaitu pengaruh Pelatihan Koin Jiwa masih berdampak hingga kurang lebih 20 hari saat pengambilan data follow-up pada kelompok eksperimen.

Manipulation check pada penelitian ini diberikan untuk kelompok eksperimen berupa tes pengetahuan, guna melihat perbedaan antara kelompok yang diberi pelatihan dengan kelompok yang tidak diberi pelatihan. Berdasarkan kategorisasi data tes pengetahuan, maka dapat disimpulkan bahwa peserta pelatihan memperoleh skor tes pengetahuan yang berada pada kategori sedang hingga tinggi.

Evaluasi pelatihan dilakukan untuk melihat kepuasan peserta pelatihan terhadap program Pelatihan Koin Jiwa. Berdasarkan kategorisasi evaluasi pelatihan terdapat 52,9\% peserta yang menyatakan puas dan $47,1 \%$ yang menyatakan sangat puas terhadap program pelatihan ini. Selain pernyataan kepuasan juga terdapat pemberian kritik dan saran untuk Pelatihan Koin Jiwa. Kritik yang diberikan antara lain pemberian materi yang kurang aktraktif, games yang kurang menarik, dan pemilihan waktu yang kurang tepat. Saran yang diberikan supaya pelatihan dapat selesai dengan lebih tepat waktu.

Hasil penelitian ini sejalan dengan penelitian terdahulu yang menyatakan bahwa pemberian psikoedukasi tentang gangguan jiwa kepada masyarakat dapat menurunkan stigma terhadap orang dengan gangguan jiwa (Byrne 2000; Corrigan et al. 2012; Corrigan, Roe, and Tsang 2011).Pemberian psikoedukasimemiliki tujuan untuk memberikan jawaban yang tepat mengenai gangguan jiwa. Selain menjawab pertanyaan yang mendasar mengenai orang dengan gangguan jiwa, pemberian 162 
psikoedukasi juga dapat menunjukkan kepada masyarakat cara memperlakukan orang dengan gangguan jiwa secara tepat (Corrigan, Roe, and Tsang 2011).

Pemberian psikoedukasi yang dipilih dalam penelitian ini berupa pelatihan. Pelatihan dipilih sebagai salah satu cara yang efektif dalam menurunkan stigma terhadap orang dengan gangguan jiwa. Hal tersebut dikarenakan pelatihan merupakan proses pemberian informasi dengan jangka waktu yang singkat, sistematis, dan terorganisir, untuk mencapai tujuan tertentu (Munandar 2008). Pelatihan juga merupakan salah satu cara untuk membantu menguasai keterampilan tertentu sehingga dapat memperbaiki kekurangan yang dimiliki (Nawawi, 2003). Materi pelatihan yang dipilih berisi tentang informasi secara jelas dan mendalam mengenai gangguan jiwa. Pemberian informasi dapat memunculkan efek yang konsisten(Sibitz et al. 2007) dalam menurukan stigma terhadap orang dengan gangguan jiwa.

\section{KESIMPULAN}

Penelitian ini berjudul Efektifitas Pelatihan Koin Jiwa dalam Menurunkan Stigma terhadap Orang dengan Gangguan Jiwa pada Mahasiswa.Penelitian ini telah melalui tahap analisa data guna membuktikan hipotesis penelitian. Analisa data yang digunakan dalam uji hipotesis yaitu Paired TTest. Kesimpulan dari penelitian ini adalah ada perbedaan yang signifikan setelah pemberian Pelatihan Koin Jiwa dalam menurunkan Stigma terhadap Orang dengan Gangguan Jiwa (ODGJ) pada Mahasiswa Fakultas Psikologi Unissula dibanding sebelum Pelatihan Koin Jiwa. Hal tersebut menunjukkan bahwa hipotesis penelitian diterima.

Peneliti juga melihat sumbangan efektif Pelatihan Koin Jiwa dalam menurunkan stigma terhadap orang dengan gangguan jiwa. Sumbangan efektif yang diberikan sebanyak $24 \%$, sisanya sebanyak $76 \%$ dipengaruhi oleh faktor-faktor lain. Berdasarkan hasil follow-up menunjukkan bahwa pengaruh pelatihan masih berdampak pada kelompok eksperimen hingga 20 hari pengukuran follow-up dilakukan.

\section{SARAN}

1. Bagi Peserta Pelatihan

Peserta pelatihan diharapkan untuk selalu memperkaya informasi menganai gangguan jiwa.Selain itu peserta juga diharapkan untuk membuat kegiatan-kegiatan yang berkaitan secara langsung dengan Orang dengan Gangguan Jiwa (ODGJ).Hal tersebut dilakukan dengan tujuan untuk membiasakan diri dalam berkomunikasi dengan ODGJ.

Peserta pelatihan juga sebaiknya dapat membantu teman-teman disekitar untuk berusaha memahami kondisi ODGJ dengan cara memperdalam informasi mengenai gangguan jiwa. Hal-hal yang dapat dilakukan yaitu dengan membagikan informasi mengenai gangguan jiwa melalui media sosial, penyuluhan, pelatihan, dan lain sebagainya.

2. Bagi Mahasiswa Psikologi

Mahasiswa psikologi diharapkan dapat mengadakan kembali Pelatihan Koin Jiwa ini. Mahasiswa psikologi sebaiknya mulai membuka diri untuk menerima informasi mengenai gangguan jiwa, dan juga perlu untuk berusaha memahami kondisi ODGJ. Hal tersebut bertujuan supaya perlakuan buruk terhadap ODGJ tidak terus menerus terjadi di lingkungan. 
3. Bagi Peneliti Selanjutnya

a. Peneliti selanjutnya sebaiknya dapat membuat penelitian sejenis dengan menambahkan materi selain psikoedukasi.

b. Peneliti selanjutnya diharapkan dapat membuat pelatihan sejenis dengan materi yang lebih mudah dipahami oleh masyarakat yang berlatar belakang non-psikologi. Hal tersebut dilakukan supaya stigma masyarakat terhadap orang dengan gangguan jiwa juga dapat menurun.

\section{DAFTAR PUSTAKA}

Arboleda-Fl' orez, Julio, and Norman Sartorius. 2008. "Understanding the Stigma of Mental IIIness : Theory and Interventions." In . Chichester: JohnWiley \& Sons Ltd.

Aruan, Daniel Arfan. 2013. “Pengaruh Pelatihan Kerja Dan Motivasi Terhadap Kinerja Karyawan PT. Sucifindo (Persero) Surabaya." Jurnal Ilmu Manajemen 1 (2): 565-74.

Byrne, Peter. 2000. "Stigma of Mental Illness and Ways of Diminishing It." Advances in Psychiatric Treatment 6: 65-72.

Ciftci, Ayse, Nev Jones, and Patrick W Corrigan. 2013. "Mental Health Stigma in the Muslim Community." Journal of Muslim Mental Health ISSN1556-4908 7 (1): 17-32.

Corrigan, Patrick W, Benjamin G Druss, and Deborah A Perlick. 2014. "The Impact of Mental IIIness Stigma on Seeking and Participating in Mental Health Care." Psychological Science in the Public Interest 15 (2): 37-70. doi:10.1177/1529100614531398.

Corrigan, Patrick W, D Psy, Scott B Morris, D Ph, Patrick J Michaels, Jennifer D Rafacz, D Ph, and Nicolas Rüsch. 2012. "Challenging the Public Stigma of Mental Illness: A Meta-Analysis of Outcome Studies." Psychiatric Services 63 (10): 963-73. doi:10.1176/appi.ps.005292011.

Corrigan, Patrick W, David Roe, and Hector W .H. Tsang. 2011. Challenging The Stigma of Mental Illness. Wiley-Blackwell. doi:10.1017/CBO9781107415324.004.

Corrigan, Patrick W, and Amy C. Watson. 2002. "Understanding the Impact of Stigma on People." World Psychiatry 1 (1): 16-20.

Crisp, Arthur H, Michael G Gelder, Susannah Rix, Howard I Meltzer, and Olwen J Rowlands. 2000. "Stigmatisation of People with Mental Illnesses." The British Journal of Psychiatry 177: 4-8.

Foster, Adriana, Sarah Hilton, Faneece Embry, Charity Pires, and Anthony O Ahmed. 2014. Measuring Attitudes Towards People with Mental Illness and People Who Are Homeless: Is A Joint Instrument Needed? Edited by Colleen Clark. Chapter 15. Nova Science Publishers.

Munandar, Ashar S. 2008. Psikologi Industri Dan Organisasi. Jakarta: Penerbit Universitas Indonesia (UI-Press). 
Efektivitas Pelatihan Koin Jiwa Dalam Menurunkan Stigma Terhadap

Orang Dengan Gangguan Jiwa Pada Mahasiswa

Proyeksi Vol. 13 (2) 2018, 156-165

Nawawi, Hadari. 2003. Manajemen Sumber Daya Manusia: Untuk Bisnis Yang Kompetitif. Yogyakarta: Gadjah Mada University Press.

Overton, Stacy L, and Sondra L Medina. 2008. "The Stigma of Mental Illness." Journal of Counseling \& Development 86: 143-52.

Seniati, Liche, Aries Yulianto, and Bernadette N Setiadi. 2015. Psikologi Eksperimen. Jakarta: Indeks.

Sibitz, Ingrid, Michaela Amering, Ralf Gossler, Annemarie Unger, and Heinz Katschnig. 2007. "Patients ' Perspectives on What Works in Psychoeducational Groups for Schizophrenia." Soc Psychiatry Psychiatr Epidemiol 42: 909-15. doi:10.1007/s00127-007-0245-5.

Sugiyono. 2014. Metode Penelitian Kuantitatif, Kualitatif Dan R \& D. Bandung: Penerbit Alfabeta.

Thornicroft, Graham, Elaine Brohan, Aliya Kassam, and Elanor Lewis-Holmes. 2008. "Reducing Stigma and Discrimination : Candidate Interventions." International Journal of Mental Health Systems 7 (2:3): 1-7. doi:10.1186/1752-4458-2-3. 